\title{
Understanding the context of multifaceted collaborations for social- ecological sustainability: a methodology for cross-case analysis
}

\author{
Jessica Cockburn $^{1}$, Michael Schoon ${ }^{2}$, Georgina Cundill $^{3}$, Cathy Robinson $^{4}$, Jaime A. Aburto $^{5}$, Steven M. Alexander $^{6}$, Jacopo A. $^{12,13}$,

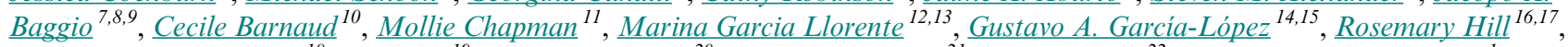 \\ Chinwe Ifejika Speranza $^{18}$, Jean Lee ${ }^{19}$, Chanda L. Meek ${ }^{20}$, Eureta Rosenberg $^{21}$, Lisen Schultz $^{22}$ and Gladman Thondhlana $^{1}$
}

\begin{abstract}
There are limited approaches available that enable researchers and practitioners to conduct multiple case study comparisons of complex cases of collaboration in natural resource management and conservation. The absence of such tools is felt despite the fact that over the past several years a great deal of literature has reviewed the state of the science regarding collaboration. Much of this work is based on case studies of collaboration and highlights the importance of contextual variables, further complicating efforts to compare outcomes across case-study areas and the likely failure of approaches based on one size fits all generalizations. We expand on the standard overview of the field by identifying some of the challenges associated with managing complex systems with multiple resources, multiple stakeholder groups with diverse knowledges/understandings, and multiple objectives across multiple scales, i.e., multifaceted collaborative initiatives. We then elucidate how a realist methodology, within a critical realist framing, can support efforts to compare multiple case studies of such multifaceted initiatives. The methodology we propose considers the importance and impact of context for the origins, purpose, and success of multifaceted collaborative natural resource management and conservation initiatives in social-ecological systems.
\end{abstract}

Key Words: collaboration; complexity; conservation; context-mechanism-outcome; critical realist methodology; governance; natural resource management; realist evaluation; social-ecological systems

\section{INTRODUCTION}

The last few decades have seen a rapid rise in the research, policy, and practice of collaboration, described as the collaborative turn in management and governance of natural resources (Imperial 2005, Harrington 2017). This period has been characterized by a growing diversity of collaborative initiatives worldwide, which are increasingly being pursued in multiresource, multiuser and multiinstitution systems, and often across a variety of scales (Lubell 2015, Cockburn et al. 2018). We are considering those collaborative initiatives, defined as processes that explicitly bring together diverse actors to work together to address socialecological sustainability challenges. These large, complex, multifaceted collaborative initiatives, recognized elsewhere as collaborations in complex, contested contexts (Cockburn et al. 2018), are playing out in a variety of social-ecological contexts. These include, for example, rural multifunctional landscapes (Schoon et al. 2017), large river catchments (Patterson 2017), large-scale biodiversity conservation areas (Hill et al. 2015), indigenous land and sea estates (Hill et al. 2012, Robinson et al.
2016), coastal marine ecosystems (Alexander and Armitage 2015), island ecosystems (Laplaza et al. 2017), and remote largescale marine protected areas (Aburto et al. 2017). Although these initiatives share the goals of working toward sustainable and equitable management and governance of ecosystems, their contexts differ, which can determine the achievement of these goals.

Understanding the role of context becomes even more important in large multifaceted collaborative initiatives. In such initiatives, social-ecological system (SES) dynamics are more complex than in the single-resource-focused initiatives (e.g., fisheries or rangelands) studied in the earlier common pool resource management literature (Ostrom 2005). We use a SES lens, recognizing that these collaborative processes are inherently characterized by dynamic, relational interactions between people and people (individually and collectively), and between people and nature. These multiple interactions mediate the services and contributions humanity derives from ecosystems and biodiversity

\footnotetext{
${ }^{1}$ Department of Environmental Science, Rhodes University, Makhanda (Grahamstown), South Africa, ${ }^{2}$ School of Sustainability, Arizona State University, Tempe, Arizona, USA, ${ }^{3}$ International Development Research Centre, Ottawa, Ontario, Canada, ${ }^{4}$ CSIRO Land and Water, Dutton Park, Australia, ${ }^{5}$ Millennium Nucleus for Ecology and Sustainable Management of Oceanic Islands (ESMOI), Departamento Biología Marina, Universidad Católica del Norte, Coquimbo, Chile, ${ }^{6}$ Environmental Change and Governance Group, University of Waterloo, Waterloo, Ontario, Canada, ${ }^{7}$ School of Politics, Security, and International Affairs, University of Central Florida, Orlando, Florida, USA, ${ }^{8}$ Sustainable Coastal Systems Cluster, University of Central Florida, Orlando, Florida, USA, ${ }^{9}$ National Center for Integrated Coastal Research, University of Central Florida, Orlando, Florida, USA, ${ }^{10}$ DYNAFOR, Université de Toulouse, INPT, INRAE, Toulouse, France, ${ }^{11}$ University of Zurich, Department of Geography and University Research Priority Program Global Change and Biodiversity, Zurich, Switzerland, ${ }^{12}$ Social-Ecological Systems Lab, Ecology Department, Universidad Autónoma de Madrid, Spain, ${ }^{13}$ FRACTAL Collective, ${ }^{14}$ Center for Social Studies, University of Coimbra, Coimbra, Portugal, ${ }^{15}$ Graduate School of Planning, University of Puerto Rico- Rio Piedras, Rio Piedras, Puerto Rico, ${ }^{16}$ CSIRO Land and Water, Cairns, Australia, ${ }^{17}$ James Cook University Tropical Environments and Societies, Cairns, Australia, ${ }^{18}$ Institute of Geography, University of Bern, Switzerland, ${ }^{19}$ Colorado College, Colorado Springs, Colorado, USA, ${ }^{20}$ Department of Political Science, University of Alaska Fairbanks, Alaska, USA, ${ }^{21}$ Environmental Learning Research Centre, Department of Education, Rhodes University, Makhanda (Grahamstown), South Africa, ${ }^{22}$ Stockholm Resilience Centre, Stockholm University, Sweden
} 
(Carpenter et al. 2012, Díaz et al. 2015). Because SES are complex adaptive systems, the function of these systems is contingent on context (Preiser 2019).

Multifaceted, collaborative initiatives are characterized by a wide range of contextual factors (or variables). This makes it challenging to compare cases, draw out common lessons, and develop theory to better understand and support collaboration in practice. Moreover, contextual factors are often beyond the control of practitioners who facilitate collaborative processes. However, these factors strongly influence the way success factors (see for example Carr Kelman et al. 2018, Ifejika Speranza 2018) or generalizable design principles (Ostrom 1990) can be put in place to increase the likelihood of success. Elsewhere in the literature on SES, the role of context in influencing outcomes has been identified as an important research frontier (Balvanera et al. 2017, Pulver et al. 2018). In addition, in the policy sphere, the Intergovernmental Platform on Biodiversity and Ecosystem Services has recently recognized the need for context-specific analytical frameworks for assessing Nature's contributions to people (Díaz et al. 2018). With growing recognition that collaboration for SES sustainability is difficult to get right (Margerum and Robinson 2016, Bodin 2017), there is an urgent need to find methodological approaches that can support learning through research and practice across a variety of contexts and scales. However, tools to critically evaluate if, and under what conditions, collaboration can be effective across different contexts are lagging (Clement et al. 2020).

We propose an approach to understanding the role context plays in multifaceted collaborations fostering social-ecological sustainability. Currently absent from the collaboration literature is a methodology that enables comparison of case studies and the identification of lessons learnt across different contexts toward a generalized understanding of collaboration in SES, similar to that in common pool resource management or SES studies more generally. We therefore examine the potential of a realist evaluation methodology (Pawson and Tilley 2004, Westhorp 2014), within a framing of critical realism (Bhaskar 2016), for this purpose. A realist methodology is well suited to this challenge because it offers a means to develop explanatory theories with a particular focus on contextual factors (Pawson 2013). Critical realism, a particular framing of realism as an ontological metatheory, supports transdisciplinary, multimethod, and multilevel research (Bhaskar 2010, Sayer 2010, Nastar et al. 2018). It allows for the bringing together of methods from distinctly different and sometimes philosophically contradictory disciplines (Mingers 2004, Nastar et al. 2018). Furthermore, critical realism is philosophically consistent with SES thinking because it views reality as an open, complex system with emergent properties (Cornell 2010, Mingers 2011, Cockburn 2018).

A key tension in the analysis of place-based collaborative initiatives lies between specificity and generalizability (Cleaver and Whaley 2018). In other words, how can we learn from indepth cases of collaborative initiatives while avoiding panaceas and overgeneralizing? However, to understand collaboration, both contextual knowledge and potential generalizations are necessary (Baggio et al. 2016). The realist approach, because it focuses on developing explanatory theories based on generalizable underlying mechanisms, can assist with identifying the influence of specific contextual factors on outcomes and processes of collaborative initiatives. It turns this tension between specificity and generalizability into a generative learning opportunity, enabling researchers and practitioners to modify and apply place-based research and learning from one particular context to multiple others. Hence, we take as a guide the question that is a key focus of realist evaluation: what works, for whom, in what circumstances, and why? (Pawson 2013) and, in recognition of the importance of learning from failure: what does not work, for whom, in which circumstances, and why not? The metatheory of critical realism, which operates as an underpinning depth philosophy, adds an explanatory dimension to the analysis of underlying mechanisms (Danermark et al. 2005), which further strengthens our ability to develop generalized theory to learn from contextually diverse cases, deepening our understanding of the “... and why?" part of this question guiding realist evaluation.

We begin by defining context and then making the case for the importance of context by explaining the nature of multifaceted collaborative initiatives. We then provide a brief review of the collaboration literature to characterize the context challenge, before presenting a methodology based on realist evaluation and critical realist metatheory. We offer this simple framework as a contribution to both researchers and practitioners. It can be used as a tool for describing, understanding, and explaining the ways that contextual factors mediate multifaceted collaborative processes and influence outcomes.

\section{MULTIFACETED COLLABORATIVE INITIATIVES AND THE NEED FOR A FOCUS ON CONTEXT}

Multifaceted collaborative initiatives: contexts of many multiples Multifaceted collaborative initiatives take on a variety of institutional arrangements (see examples in Table 1). In these initiatives, collaboration is often pursued as a means of building consensus and also of overcoming institutional fragmentation. It is used to link across different types of institutions (regulatory and nonregulatory instruments; public and private owners and managers; customary and nation-state legal systems) and across scales (e.g., local, state, national, and international; Hill et al. 2015). It is also a means of recognizing and benefitting from multiple ways of knowing, e.g., Indigenous land users, scientists, and government officials (i.e., supporting transdisciplinarity). As a result, collaboration for management and governance of natural resources today is a more complicated and challenging endeavor, characterized by many multiples (Poteete 2012; Table 1).

The illustrative examples of collaborative initiatives presented in Table 1 are characterized by some or all of the following multiples: (1) they involve multiple actors or stakeholders (beyond only direct resource users); (2) they seek to manage or govern multiple resources or ecosystem services simultaneously and collaboratively (which are often contested and embedded within large, complex ecosystems); (3) they work toward multiple objectives for the resource system (e.g., subsistence resource use, agriculture, conservation, recreation, climate change adaptation); (4) there are multiple institutions, within the system (e.g., a diversity of land tenure or property rights regimes or a range of regulatory, nonregulatory, and customary law institutions); (5) and they often operate at or across multiple scales.

In practice, bringing about equitable and sustainable collaborative management and governance in the context of these many multiples is a significant challenge (Sandström 2009, 
Table 1. Illustrative examples of a diversity of multifaceted collaborative initiatives and the many multiples that characterize them in complex social-ecological systems (SES).

\begin{tabular}{|c|c|c|c|c|c|}
\hline \multirow[t]{2}{*}{$\begin{array}{l}\text { Examples of collaborative initiatives in } \\
\text { SES }\end{array}$} & \multicolumn{5}{|c|}{$\begin{array}{l}\text { Examples of the many multiples that characterize multifaceted collaborative initiatives } \\
\text { (Asterisks indicate the level of multiplicity, from low to high: } \\
\qquad *=\text { single, } * *=\text { two, } * * *=\text { more than two.) }\end{array}$} \\
\hline & Resources $^{\dagger}$ & Actor groups ${ }^{*}$ & Objectives & Institutions & Scales \\
\hline $\begin{array}{l}\text { Common pool management of a fishery } \\
\text { for sustainable use at local level (Lobe } \\
\text { and Berkes 2004) }\end{array}$ & $*$ & $*$ & $*$ & $*$ & $*$ \\
\hline $\begin{array}{l}\text { Managing landscapes for } \\
\text { multifunctionality to govern a diverse } \\
\text { suite of ecosystem services (O'Farrell et } \\
\text { al. } 2010 \text {, Cockburn et al. 2020). }\end{array}$ & $* *$ & $* *$ & $* * *$ & $*$ & $* *$ \\
\hline $\begin{array}{l}\text { Collaborations to reconcile biodiversity } \\
\text { conservation and sustainable development } \\
\text { in biosphere reserves (Schultz et al. 2011, } \\
\text { Coetzer et al. 2014). }\end{array}$ & $* * *$ & $* * *$ & $* *$ & $* *$ & $* *$ \\
\hline $\begin{array}{l}\text { Landscape-scale biodiversity conservation } \\
\text { initiatives (Hill et al. 2015). }\end{array}$ & $* *$ & $* *$ & $*$ & $* *$ & $* *$ \\
\hline $\begin{array}{l}\text { Basin-scale and multilevel governance } \\
\text { initiatives for water use and management } \\
\text { (Robinson et al. 2015, Bark et al. 2016, } \\
\text { Margerum and Robinson 2016, Ifejika } \\
\text { Speranza et al. 2018). }\end{array}$ & $*$ & $* * *$ & $*$ & $* * *$ & $* * *$ \\
\hline $\begin{array}{l}\text { Collaborative interactions between } \\
\text { marine protected areas and local } \\
\text { Territorial User Rights for Fisheries } \\
\text { governance systems (Aburto et al. 2014, } \\
\text { Cárcamo et al. 2014). }\end{array}$ & $* *$ & $* * *$ & $* *$ & $*$ & $* *$ \\
\hline $\begin{array}{l}\text { Collaborative management to recognize } \\
\text { Indigenous rights, and a diversity of } \\
\text { subsistence and cultural uses of natural } \\
\text { resources across a landscape (Thondhlana } \\
\text { et al. 2015, Robinson et al. 2016). }\end{array}$ & $* * *$ & $* * *$ & $* * *$ & $* * *$ & $* *$ \\
\hline
\end{tabular}

Saunders 2014, Bodin 2017, Ayala-Orozco et al. 2018). Doggedly, or even blindly, seeking collaboration in such contexts may therefore be naïve at best, and destructive at worst. In some cases, local people may not want collaboration, or they are divided: some want to work in a collaborative way, and some do not want any kind of collaboration with external agencies or NGOs (Paredes et al. 2019). The multiplicity of features poses a challenge to understanding when, where, and why collaboration works or does not work and might in some circumstances even have to be abandoned (Margerum and Robinson 2016).

\section{Going beyond "context matters"}

Although most can agree that context matters, there is often a lack of clarity on what it means exactly, beyond the idiosyncratic distinctions of a given place. According to Pulver et al. (2018), context is defined as the setting for the SES under study, or for Djenontin and Meadows (2018) it is the environment in which the project takes place and other factors often beyond the control of researchers. That is, it consists of those factors that are "givens" not to be directly changed by any proposed intervention or focal process (for example, a collaborative initiative). These might be the nature of the soils in a particular landscape, or the nature of the national government, or traditional gender roles. Once we decide that we want to change the nature of government or traditional gender roles, they are no longer context, but our central focus. This is a helpful frame for distinguishing between context and program or model because the intention determines the bounding or scope of the object of interest versus its context. However, we argue that context cannot be ignored because it is "not a passive backdrop to a system but an active agent in itself that enables or inhibits systemic agency" (Preiser 2019:710). As Pawson (2013:36) points out: "the context of an intervention, the circumstances in which it is played out, constitutes another endless source of complexity...context we have learnt, is not unwelcome noise, not a confounding variable to be controlled forbut an integral part of a programme." As the examples demonstrate, context is therefore more than simply the setting or the environment: it is a source of the deeper underlying mechanisms that interact with the program mechanisms (or the mechanisms or events introduced through the collaborative initiative); the latter can be manipulated, the former are less amenable to change. Therefore, context has an important mediating influence on the way in which design principles (Ostrom 2005) or success factors (Carr Kelman et al. 2018) play out, and is often the aspect of an initiative that is most difficult to change or influence. For example, the type of resource being managed as 
Table 2. Four distinct bodies of literature relevant to understanding collaboration in social-ecological systems (adapted from Sandström 2009, Saunders 2014, Cleaver and Whaley 2018, and Cockburn et al. 2018).

\begin{tabular}{|c|c|}
\hline Body of collaboration literature & Theoretical characteristics and origins \\
\hline $\begin{array}{l}\text { Common property regimes or common pool } \\
\text { resource management (Ostrom 1990, 2005). }\end{array}$ & $\begin{array}{l}\text { Based on new institutional economics (North 1991). Has a strong rationalist and positivist orientation, } \\
\text { with recent shifts toward complexity thinking. } \\
\text { Focus is on direct resource users; actors seen as "fallible, norm-adopting individuals who pursue } \\
\text { contingent strategies in complex and uncertain environments" (Ostrom 1990:185). }\end{array}$ \\
\hline $\begin{array}{l}\text { Collaboration in SES: includes comanagement } \\
\text { (Carlsson and Berkes 2005), adaptive } \\
\text { comanagement (Armitage et al. 2007), and } \\
\text { adaptive governance (Folke et al. 2005). }\end{array}$ & $\begin{array}{l}\text { Draws on common pool resource theory, but also on political ecology and SES resilience; strong } \\
\text { emphasis on adaptive, learning-based approaches. Based on complexity or systems thinking. Actors } \\
\text { seen as embedded in SES; wide range of actors recognized. }\end{array}$ \\
\hline $\begin{array}{l}\text { Collaborative governance (Wondolleck and } \\
\text { Yaffee 2000, Ansell and Gash 2007, Emerson et } \\
\text { al. 2012). }\end{array}$ & $\begin{array}{l}\text { Based on deliberative democracy and a pluralistic understanding of society, drawing on a range of } \\
\text { philosophical orientations including constructivism, positivism, and holism. } \\
\text { Actors seen as socially embedded; a broader suite of actors is recognized; more recent influence of } \\
\text { political ecology has resulted in more focus on power dynamics. }\end{array}$ \\
\hline $\begin{array}{l}\text { Collaboration across customary law and nation- } \\
\text { state legal systems (Hill et al. 2012, Cundill et al. } \\
\text { 2013, Thondhlana et al. 2015, von der Porten et } \\
\text { al. 2015). }\end{array}$ & $\begin{array}{l}\text { Draws on postcolonial theory (encouraging methodological, epistemological, and ontological } \\
\text { pluralism) and links to political ecology and Indigenous governance literature. } \\
\text { Actor analysis includes as key the recognition of Indigenous peoples as holders of both rights and } \\
\text { institutions; recognizes the roles of power imbalance among actors. }\end{array}$ \\
\hline
\end{tabular}

well as the need for more or less investment in infrastructure affects the importance of different design principles (Baggio et al. 2016).

Policy and planning contexts can also influence the way in which collaboration is designed or emerges. They also affect the degree to which some groups, such as Indigenous peoples, are able to meaningfully participate in decision making (Duncan et al. 2018) or are represented by government institutions (Aburto and Gaymer 2018). At the same time, other contextual factors such as market integration, population pressure, and history of the resource system can void or increase the likelihood of collectively managing resources sustainably (Barnett et al. 2016). The importance of context is additionally underscored by calls for more situated and nuanced understandings of social-ecological dynamics, which take social-cultural and historical features into account, for example through more in-depth, qualitative research (Cote and Nightingale 2011). With respect to community-based natural resource management initiatives, Fabricius et al. (2013) argued that conservation projects should not be evaluated generically but that only a case-by-case approach can provide a justified and objective state-of-affairs of such initiatives.

In seeking to understand and support collaborative initiatives, we as researchers also become part of the context. Because we adopt a complex systems approach to our research in SES, we can no longer consider ourselves separate from the object of our research and need to be critically reflexive actors within the system (Audouin et al. 2013, Preiser 2019). Thus, it is worthwhile to note the researchers' insider-outsider positionality in research because our relationships with other actors, our legitimacy, our lived experiences, and our own agendas become key components of the context (Barnaud and van Paassen 2013, Mathevet et al. 2014).

\section{CHARACTERIZING THE CHALLENGE OF CONTEXT FOR COLLABORATION: A REVIEW}

We now briefly turn to a review of existing literature to identify the challenges of understanding the influence of context on the outcomes of collaboration (Table 2). Our review synthesizes insights from four published studies in which more detailed reviews of literature were conducted (Sandström 2009, Saunders
2014, Cleaver and Whaley 2018, Cockburn et al. 2018), and is brought together with the authors' experience of studying and facilitating collaborative initiatives. We selected these four studies based on their questioning of the existing literature specifically in terms of its engagement with the complexity of context in contested, multifaceted collaborative resource management.

Our analysis leads us to identify four related bodies of literature that have each addressed various aspects of collaboration and which are based on diverse theoretical understandings of actors and their social interactions (Table 2). Furthermore, this literature review has led us to identify two distinct challenges related to the question of context that remain critical to address in the collaboration literature, and which we discuss: (1) the interdependencies among actors and resource systems arising out of the complexity of the SES and the multiplicities described earlier; and (2) the social and power dynamics emerging from the social-cultural, political, and institutional contexts in which collaborative initiatives play out.

\section{Interdependencies among actors and resource systems arising out} of system complexity

Social-ecological systems are inherently complex. Ecological and social dynamics and interactions among and between them are characterized by nonlinear dynamics and thresholds, which are often difficult to observe in part due to slow or delayed feedbacks (Levin et al. 2013). At the same time, within such systems, knowledge is often fragmented, knowledge sources or ways of knowing are contested, and objectives are multiple (Tengö et al. 2014). To add to this, the problems we need to address in SES are often nested and interrelated with many other problems. In other words, problems are also interdependent, and solutions often involve difficult trade-offs especially when multiple objectives or resource conflicts exist.

Collaboration is therefore necessary to bridge knowledge fragmentation, increase the understanding of the complex dynamics existing in SES, and address resource conflicts (Cockburn et al. 2018). However, existing theories of collaboration do not sufficiently capture interdependencies among actors and how they interact with the ecosystem (i.e., with 
resource units and resource systems) and among one another (Hinkel et al. 2015), especially in more complex, multifaceted initiatives (Table 1). Interdependence among actors is mediated by the institutions, social-cultural discourses, and economic context in which collaborative processes play out, i.e., by the social-political context (Zachrisson and Beland Lindahl 2013).

Recognizing the multiple values associated with ecosystem services and Nature's contributions to people allows a further understanding of the complexity of these social interdependencies (Díaz et al. 2018). Although Ostrom's (2009) SES framework has sought to refine the understanding of this interdependence between actors, governance systems, and the resources or resource system, i.e., the individual and collective human-nature relationships within collaborative processes, it is still not fully developed or operationalized.

Despite a lived reality of multiples, much of the literature on collaboration has thus far focused on single resources (fisheries, water, etc.) and on interactions among the users and managers of these single-resource systems. This is in spite of wide acknowledgement that coping with complex SES involves other types of resources like ecosystem services, which are less visible, more diverse, and complex, and operate across multiple scales (Barnaud et al. 2018, Díaz et al. 2018). Additionally, although literature on collaboration often focuses on local resource users as the main actors, there is indeed a wide range of actors operating at multiple scales (Berkes 2006), with different interests in the resource system (Oberlack et al. 2018). Moreover, property rights are often not clearly defined in multiresource, multiuser systems, or there may be contestation or conflict around property rights (Sandström 2009). Collaboration is taking place in increasingly complex institutional settings (Lubell 2015) including within Indigenous contexts that are co-occurring with industrial extractive industries (Wilson and Stammler 2016). Therefore, careful attention needs to be paid to understanding how the multiple interdependencies and interactions among actors, resources, and institutional arrangements mediate the socialecological outcomes of collaboration.

\section{Power dynamics emerging from social-cultural, political, and institutional contexts}

One key challenge in understanding and managing collaborative processes comes from the existence of unequal power relationships. This challenge becomes more important and difficult to address in contexts characterized by multiple actors, scales, and institutions, in which power imbalances are deeper and have a stronger influence on collaborative processes and outcomes (Sandström 2009, Brisbois and de Loë 2016, Cleaver and Whaley 2018). A multiplicity and diversity of actors suggests that social interactions will have a much stronger influence on collaborative processes and outcomes than we previously thought. Power dynamics emerge from the social-cultural, political, and institutional contexts in which the collaboration is embedded. Critics of the common pool resource and SES collaboration literature have identified this gap. They call for more nuanced research to better assess and understand the social-relational, cultural, and political complexities of the context in which resources are managed collectively (Cleaver 2002, Barnaud et al. 2010, Patterson 2017). For example, Ferreyra et al. (2008) suggested that policies that encourage collaborative governance of watersheds and natural resources at scales appropriate for the ecological issue do not sufficiently account for the social-political complexities of human communities. They suggested that efforts should be made to better align collaborative governance initiatives with existing social and political processes. This points to the need for more situated understandings of the social context in which collaborative processes play out (Cote and Nightingale 2011, Saunders 2014), and in particular to a better understanding of how power dynamics and unequal social relations influence collaboration (Robards et al. 2011, Barnaud and van Paassen 2013, Brisbois and de Loë 2016, Cleaver and Whaley 2018). To this end, Saunders (2014: 636) argues that common pool resource scholarship "oversimplifies" the context of the project "because it offers little or no direction to deal with the social embeddedness of resource use or implications of different stratifications." Thus, many collaborative SES projects run the risk of being unresponsive to the social realities of context, particularly when one recognizes, as we do here, that context is more than a backdrop or a setting.

The issues of power and recognition are even more pronounced in the context of limited or eroding statehood, in which formal governance mechanisms are absent or limited. This issue is especially prevalent in Global South contexts in which there may be limited statehood or eroding formal governance (see for example, Ayala-Orozco et al. 2018), or strong pressures from foreign states and corporations (Watts 2004); as well as in contexts of the Global North, where corporations and other powerful 'elites' also strongly influence state decision-making in collaborative environmental governance processes (see for example Brisbois and de Loë 2016 and Wolin 2008). Collaborative contexts in these situations (see also Cockburn et al. 2019, 2020) are often characterized by higher heterogeneity in terms of cultural, political, ontological, and epistemological differences between actors (Laplaza et al. 2017). In such cases, alternative governance approaches have emerged, for example through the influence of nongovernment or civil society organizations (AyalaOrozco et al. 2018). Moreover, critiques of conservation and natural resource management literature, which relate to the marginalization of certain groups, knowledges, and worldviews, are legitimate (Lansing et al. 2015) and need to be addressed to support more equitable collaborations in SES. Accordingly, some authors have called for a pluralistic approach to collaboration in more heterogeneous contexts because consensus-based processes could lead to marginalization of minority voices and perspectives, bringing the equity of collaborative outcomes into question (Barnaud and van Paassen 2013, Cockburn et al. 2019).

\section{Constraints to understanding and supporting collaboration}

The commons scholarship has of course made significant contributions and is drawn from situated analyses of collaborative natural resource management in various contexts (Ostrom 1990). However, Ostrom and colleagues (2007) have highlighted their limitations in increasingly complex systems. In contexts of high social-ecological complexity characterized by many multiples (Table 1), interdependencies, and uncertainty in both ecological and social dynamics, the ability of diverse groups of heterogeneous actors to collaborate is limited (Patterson 2017, Ayala-Orozco et al. 2018). Understanding the influence of contextual factors and comparing lessons learnt across these contexts becomes critical but extremely difficult. The critiques 
and challenges discussed indicate that existing theory has struggled in some ways to address this new situation, and novel methodological approaches are needed to better understand the complexities of these multifaceted collaborative initiatives.

The common pool resource literature made important advances in our understanding of collaborative resource management. However, increasingly there is a need for generalized lessons or design principles, similar to those for long-enduring common pool resource institutions, which explain more complex systems and multifaceted forms of collaboration (Table 1). The literatures described in Table 2 have each made important contributions toward this end. For instance, the adaptive comanagement literature has shown the importance of learning when managing complex resource systems. Collaborative governance has given attention to a greater suite of actors, as well as the forms in which they participate. And finally, Indigenous governance literature has drawn attention to historical injustices and the importance of nonwestern epistemologies. What then might a new set of design principles look like? Design principles that are applicable to the current state of resource governance in all its complexity? As a first step toward this goal, we suggest a methodology to guide analysis and comparison across diverse collaborative processes. Design principles could then be elucidated from the application of the methodology in such analyses.

\section{UNDERSTANDING HOW CONTEXT MATTERS FOR COLLABORATION: A CRITICAL REALIST METHODOLOGY}

\section{The case for a critical realist methodology}

Any outcome (positive or negative) results from a combination of context, which made this outcome possible, and a collaborative process or intervention, which has an impact on the context through various mechanisms. What makes an assessment of the outcomes of a collaborative process difficult, is the fact that it is difficult to know which outcomes emerge from the context and which emerge from the collaborative process or intervention itself. Thus, we now turn to investigating the potential of realist approaches to addressing this challenge.

Realist evaluation and realist synthesis have become wellrespected methodologies for evaluating program outcomes and developing substantive theory across fields such as healthcare, education, agricultural development, and natural resource management (Rogers 2008, Mayne and Stern 2013, Pawson 2013, Douthwaite and Hoffecker 2017, Ward 2017, McLain et al. 2018). Realist evaluation offers a means to develop both generalizable theory and an associated new set of design principles to help us understand and support multifaceted collaborative initiatives, based on an understanding of how context influences collaborative processes and outcomes, i.e., How or why does this work, for whom, in what circumstances? (Pawson 2013, Westhorp 2014). The explanatory power of realist evaluation expressed in these questions is particularly well-suited to understanding the influence of context. Although context is often included as a variable in other evaluation frameworks (for example, in the logical frame used by Djenontin and Meadow (2018) or in Plummer and Armitage's (2007) resilience-based framework for evaluating adaptive comanagement), the way it is incorporated in realist evaluation positions it less as a background variable, and more as a key explanatory variable for understanding collaborative outcomes.

In addition to a realist methodology, we argue for a critical realist ontology as the metatheory to inform how realist methods are used, i.e., we are proposing a critical realist methodology (see also Nastar et al. 2018). Collaborative initiatives that play out in SES are complex adaptive systems with multiple entwined roots. Their outcomes are influenced by the collective choices of the participants (actors, stakeholders, rights-holders, resource users, etc.), which are mediated (constrained or enabled) by the contexts in which they are embedded. Critical realism is a philosophy of science (or metatheory) arguing that there are multiple layers to reality (a world of multiples, but stratified, i.e., there are causal relations between the layers). A stratified ontology (worldview) requires multiple ways of knowing and enquiry and its methodological derivatives therefore encourage methodological pluralism and a blend of methods across the qualitative, quantitative, and mixed methods spectrum (Sayer 2010, Pawson 2013). Such multimethod approaches have been regarded as key for conducting research on collaboration that is both situated and context specific, and generalizable across contexts (Barnett et al. 2016). A realist approach allows multilevel analysis and comparative case study research because it can be used to describe and analyze collaboration within cases, across cases (see Box 1 for an example), for meta-analysis, for theory building (see Fig. 1 for examples), and for evidence synthesis such as systematic reviews (McLain et al. 2018). Moreover, critical realism is wellsuited as an ontological basis to interdisciplinary and transdisciplinary studies (Bhaskar et al. 2010) because it can operate as a metatheory (or a philosophical underlaborer) for both the biophysical sciences and social sciences (Mingers 2004, Cornell 2010, Price 2014), a characteristic that it shares with pragmatism (Morgan 2007, Creswell 2009). Bhaskar, the lead proponent of critical realist, argued that "because we are both embodied as well as conceptualising beings, the human sciences must be prepared to use quantitative as well as qualitative research, that is, to measure and count our material features, as well as record and interpret our conceptual activity - employ, in effect, mixed-method research" (2016:57). This is even more so the case when transdisciplinary studies traverse both biophysical and social domains (Cornell 2010), and critical realism's commitment to an emancipatory science toward a freely flourishing society enables researchers to be explicit about their role as change agents in the world (Bhaskar et al. 2010, Bhaskar 2016).

With its fundamental ontological view that reality is an open system characterized by emergence, critical realism is a suitable underlying philosophy for complexity theory (Preiser 2019) and well-aligned with a SES lens (Mingers 2011, Cockburn 2018). Critical realism posits a layered reality or ontology, also called a depth ontology, made up of three layers nested within one another: the empirical (observable), the actual (in which events occur), and the real (all-encompassing layer of reality from which deeper mechanisms operate to influence events from which observable empirical outcomes emerge; Bhaskar 2016). For example, we can observe empirically that farmers cannot seem to afford the costs of responsibly stewarding the soil (the empirical); we can see that this emerges in response to events such as policies that don't reward farmers for such investments (the actual), which 
Fig. 1. Example applications of realist evaluation methodology to understand multifaceted collaborations. The examples illustrate potential variables and context-mechanism-outcome (CMO) configurations. Note: For the sake of illustration, the examples of theoretical propositions given in the figure are somewhat simplistic. Things are obviously more complex, and it is precisely the objective of the method we propose to uncover this complexity.

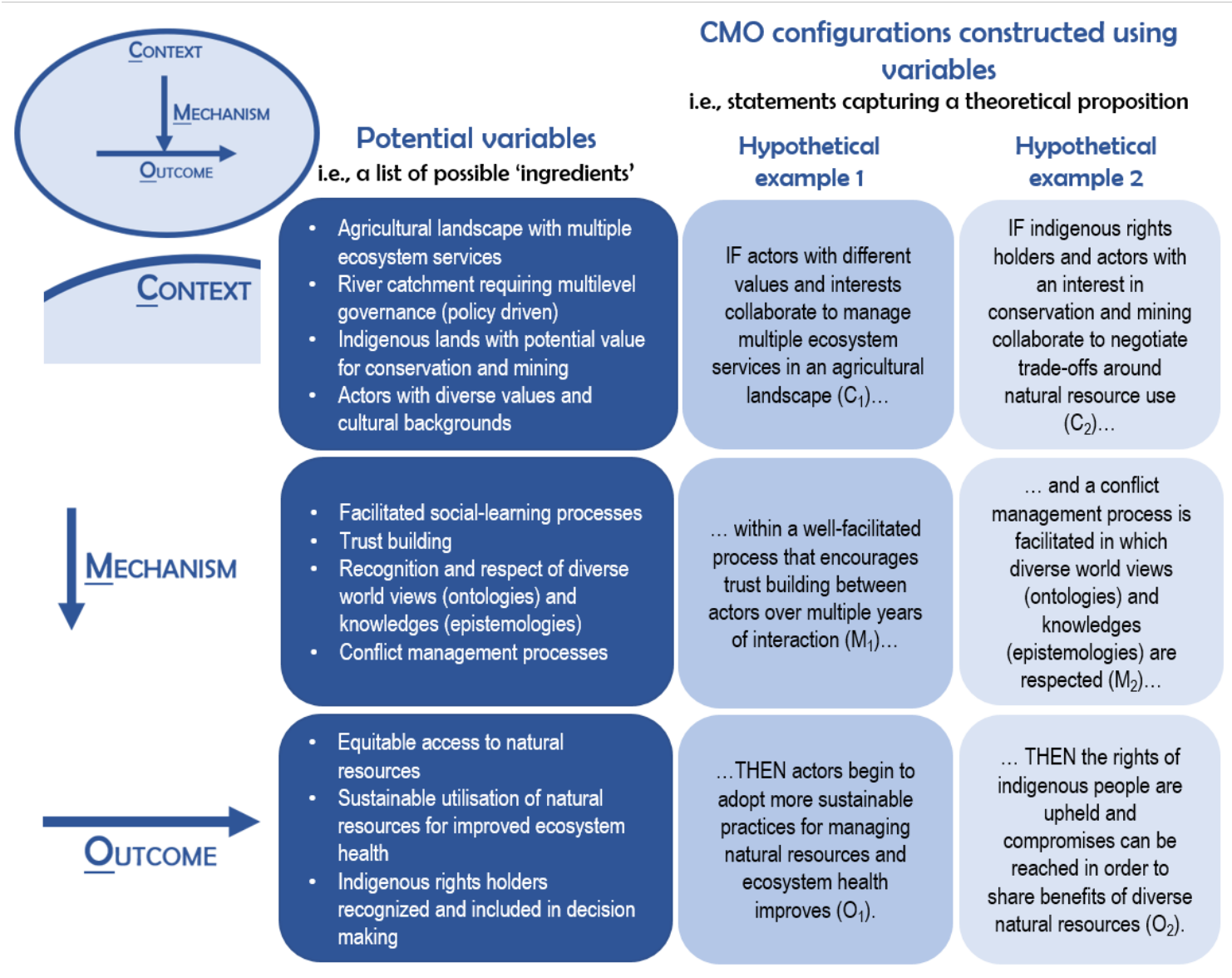

are strongly influenced by the neoliberal capitalist economy (the real) that drives much of agricultural policymaking (Cockburn 2018). This layered understanding of reality enables investigations of causal explanations of social-ecological phenomena that go deeper than visible empirical observations or events, i.e., the underlying mechanisms that generate observable outcomes within a given social-ecological context (Danermark et al. 2005).

\section{Applying realist evaluation methodology to understand the context of collaboration: the context-mechanism-outcome (CMO) framework}

The basic schema of context-mechanism-outcome (CMO) used in realist evaluation methodology (Pawson and Tilley 1997, Westhorp 2014) can be a useful analytical framework to guide research on multifaceted collaborations in SES. In particular, it can enable an elucidation of how contextual factors interact with other factors to produce collaborative outcomes. The CMO methodology aligns well with the diagnostic framework for adaptive comanagement proposed by Plummer et al. (2017), which directs attention to "setting" (context), "antecedents and processes" (mechanisms), and "outcomes" to facilitate comparative analyses. The specific features under study in adaptive comanagement initiatives include constellations of actors (contextual factors), as well as activities, practices, and processes of collaboration and learning (mechanisms). However, the CMO framework allows for a broader range of mechanisms to be determined through various modes of inference including deduction, induction, and retroduction (Danermark et al. 2005), and for a focus on how context influences collaboration (see examples in Fig. 1 and Box 1). Note: retroduction is a mode of inference or reasoning whereby "researchers move beyond empirical and actual domains to construct hypotheses or explanations of generative mechanisms that would account for the subject of their studies" (Nastar et al. 2018).

By distinguishing between context, mechanism, and outcomes, the CMO framework facilitates comparison across diverse case studies and allows for development of explanatory theories to explain collaborative outcomes. Eventually, we hope the CMO framework can be used to structure an overall theory of how multifaceted collaborative initiatives work to support sustainable 
Fig. 2. Cases of collaborative landscape stewardship studied to understand collaboration and the influence of context through the application of the realist CMO framework (see Box 1; Figure from Cockburn 2018 and Cockburn et al. 2020).

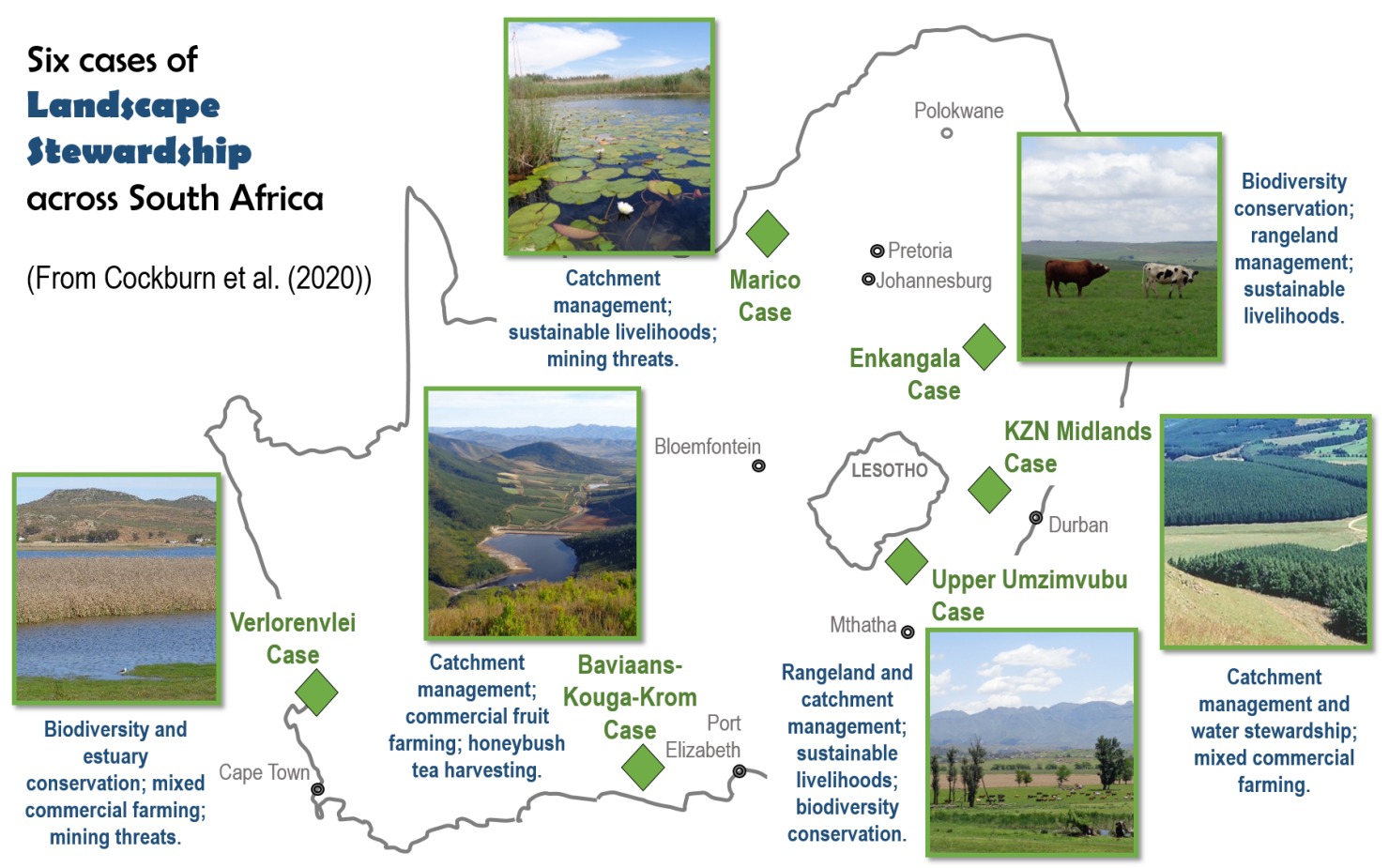

use of natural resources, by using it to structure the comparison of a place-based case-by-case analysis or comparative case study approach. This can be done by developing sets of contextmechanism-outcome (CMO) statements or configurations (e.g., In this context, that mechanism generates this outcome; Fig. 1).

A CMO configuration is a hypothesis that the program works $(\mathrm{O})$ because of the action of some underlying mechanisms (M), which only comes into operation in particular contexts (C). If the right processes operate in the right conditions, then the program or initiative is likely to succeed (Fig. 1). The theory is causal and conditional, and is a testable proposition that can be presented as an equation: $\mathrm{C}+\mathrm{M} \rightarrow \mathrm{O}$ (Pawson 2013). Presenting the configuration as an equation might lead one to interpret realist evaluation to be informed by linear thinking, but this is not the case. Realist evaluation is explicit about its complexity underpinnings (Pawson 2013, Douthwaite et al. 2017), and the equation is merely a simple heuristic to support analysis and theory development.

The CMO framework is based on three types of variables: (1) contextual variables, (2) mechanism variables, and (3) outcome variables (Fig. 1). Contextual variables are independent variables, which describe the social-ecological (pre-) conditions in which the collaboration plays out. Elucidating these contextual variables in relation to other variables enables a deeper analysis of the role of context in collaborative initiatives. Mechanism variables are plausible causal variables that explain the success (or lack of success) of a collaboration; they might be considered the elements or features of interventions or ongoing processes that are required for a collaboration to work, often called success factors (Carr Kelman et al. 2018) or design principles (Ostrom 1990). In contrast, they could also be identified as barriers that prevent the sustainability outcomes sought (Box 1). Outcome variables are dependent variables, which indicate whether the collaboration is a success, i.e., they are indicators of success, or the objectives of the collaboration such as social and/or ecological sustainability outcomes.

The CMO framework, most closely associated with realist evaluation methodology, of which Pawson (2016) was an early proponent, is not necessarily a critical realist methodology (critical realism is a philosophy or metatheory about ontology); i.e., the CMO framework is a methodology that is not always informed or underpinned by this philosophy. Although Pawson has distanced his own application of the methodology from Bhaskar's critical realism (Pawson 2016), we take a pragmatic stance and argue, however, that critical realism is compatible with the methodology and adds an important depth dimension, which is illustrated in Box 1.

Box 1 presents a brief example of how the realist evaluation CMO framework can be used to describe and analyze collaborative processes, and how it gives a deeper insight into contextual factors. The example is based on a study investigating collaboration among multiple actors in multifunctional landscapes across South Africa (Cockburn 2018, Cockburn et al. 2020; Fig. 2). Although this example illustrates the application of the CMO framework to a multicase comparison, it is also applicable to single in-depth studies, which can later be brought together in a comparative manner for analytical purposes. 


\section{Box 1:}

Applying the context-mechanisms-outcomes framework to understand multifaceted collaboration and the influence of context: insights from a study on collaborative landscape stewardship in South Africa (Cockburn 2018).

Landscape stewardship initiatives have seen increasing application in South Africa. Multistakeholder collaboration is a key challenge in such initiatives, which are typically complex and multifaceted (Table 1). This study employed a transdisciplinary multicase study approach, underpinned by a critical realist methodology, to investigate the enablers and barriers of collaboration for landscape stewardship. A map of South Africa illustrating the cases and their key features is shown below (Fig. 2). Drawing on the empirical findings of the study, the CMO framework can be used to describe insights about collaboration as follows:

Context: the six cases within the multicase study all shared the following contextual features: multiple stakeholders with different and sometimes competing interests and objectives in the landscape (both within and among groups of actors with interests in e.g., agriculture, tourism, rural development, biodiversity conservation); high diversity among stakeholders in terms of social, cultural, and political characteristics; unequal power relations and unequal sharing of ecosystem benefits among stakeholders influenced by historical political arrangements; multiple interrelated resources or ecosystem services of interest; limited influence of formal governance structures on collaboration; NGOs acting as facilitators of collaboration. These contextual features point to the literatures associated with collaborative governance and collaboration across customary and nation-state legal systems (Table 2) as helpful in identifying underlying mechanisms.

Mechanisms: across all cases, the following underlying mechanisms that influenced collaboration were identified, making it difficult to achieve sustainable outcomes from collaboration: first, the deep-seated conflict between agriculture and conservation makes stewardship and collaboration a difficult task; stewards are forced to play a balancing act between livelihood needs and stewardship responsibilities. Second, we live in a world in which it is difficult to care for and take responsibility for our actions with distant or tele-coupled impacts or interactions with nature and our fellow humans. For example, agricultural policies in South Africa drive commercialization at the expense of environmental sustainability and social justice, making it difficult for stewards to care and share across the landscape. Third, South Africa is a deeply divided and unequal society. Such deep structural inequalities make stewarding and sharing natural resources difficult. To overcome these mechanisms, which are operating as barriers, enabling mechanisms such as social learning processes, long-term relationship and trust-building across interest groups are recommended, and showed promise in some cases.

Outcomes: the cases demonstrated various outcomes from the collaborative processes. There was some success at building collaboration and new interpersonal relationships at the local level among diverse stakeholders, success in achieving stewardship outcomes such as sustainable livelihoods (e.g., permaculture gardens), innovative farming practices, improved catchment management, and biodiversity conservation. However, there were difficulties in building collaboration between stakeholders of different interest groups and race groups, difficulties in linking local collaborative activities with higher level processes, and difficulties in enforcing natural resource management legislation in the absence of government compliance monitoring. These outcomes in turn recursively influence the social-ecological context at local and possibly also regional scales, through new relationships and sustainability practices.

Applying the CMO methodology in the study presented in Box 1, within a critical realist framing, enabled a situated, transdisciplinary analysis of collaboration that paid particular attention to the influence of context on collaborative outcomes and processes. The study drew on a range of disciplinary knowledges spanning social and ecological sciences, and on the local, experiential knowledge of stewardship practitioners through a two-year knowledge coproduction process (Cockburn et al. 2019, 2020). Applying a realist analysis in an inductive and retroductive manner revealed the influence of underlying mechanisms beyond the empirical observations made in the cases. Elucidating these mechanisms helped to explain how broader contextual features, for example at the national and global levels, influenced collaboration in a particular place (e.g., the influence of historical Apartheid policies in South Africa, or of global neoliberal economic models). The CMO framework allowed for analysis of not only what the contextual factors are, but how they interact with other variables. Thus it enabled, for example, a better understanding of power dynamics in the collaborative processes, which were not immediately evident from the empirical data, but once identified helped to explain some of the patterns evident in the data (e.g., concerns about race relations and historical inequalities that emerged across most cases).

Moreover, as the study was framed as a transdisciplinary study, the experiential knowledge of practitioners was considered important. Critical realism allowed for the accommodation of diverse actors' viewpoints and multiple knowledge systems. It also enabled the integration of both academic knowledge (e.g., from the literature and as analyzed in the formal data analysis process of the study) and the practice-based knowledge of practitioners to develop theory (see Cockburn et al. 2019, 2020).

Similarly, we recognize that in many contexts, different perceptions abound about what exists in the setting (i.e., different ontologies), as well as different knowledge systems with different ways of knowing what is true (epistemologies; see for example the diversity of ways in which collaboration has been conceptualized and studied as shown in Tables 1 and 2). The analysis of contextual factors helps point to the bodies of literature (Table 2) that are going to be most useful in identifying mechanisms at play. The CMO framework, together with a critical realist metatheory that enables theoretical and methodological pluralism (Gorski 2013), can take account of this and support a pluralistic approach through recognition of multiple and diverse pathways toward 
sustainability (Leach et al. 2013) operating in multiple contexts, through multiple mechanisms, with diverse outcomes for different people in the collaboration.

Considering that collaborative governance often entails a transdisciplinary approach (for example, including partnership between researchers, practitioners, and local people), recursive and interactive interlinkages between context, mechanisms, and outcomes deserve attention because they support reflexivity and learning among the actors involved (Wiesmann et al. 2008). To encourage this collaborative and learning-oriented way of understanding and supporting collaborations, it may be valuable to illustrate the CMO less as a linear equation and more as a cyclical, iterative tool to support research, learning, and practice in place-based collaborations, i.e., from $\mathrm{C}+\mathrm{M} \rightarrow \mathrm{O}$ to $\mathrm{CMOC}$. Moreover, the researcher becomes part of the context. Therefore, reflexivity in conducting the research becomes paramount in the iterative, collective learning process, which this framework could support.

As we have indicated, in some instances this learning and reflexivity might bring researchers and partners to question the feasibility and equity of collaboration in certain contexts. The collaborative turn (Imperial 2005) may have inadvertently led us into a naïve optimism about collaboration as a panacea. If we are serious about taking context into account, we may in some cases need to abandon our efforts toward large-scale blankets of collaboration or consensus, in favor of more pluralistic patchwork or bricolage approaches to working in social-ecological systems (Wollenberg et al. 2005, Cleaver 2012, Barnaud and van Paassen 2013, Cockburn et al. 2019).

\section{Limitations of the methodology}

Any methodology has associated challenges and in the case of the CMO method for analyzing cases, a recognized challenge is the difficult of distinguishing between context and mechanisms. As noted in the introduction, context is not directly addressed by the intervention or collaborative process in focus, but it is the source of other mechanisms that mediate the response of the system to the collaborative process. For example, power differentials between mining companies and Indigenous land users are not easily shifted, could constrain collaboration, and are therefore usually a mediating contextual mechanism.

A second challenge is the need to analyze complex cases more deeply, to identify what lies behind or deeper than a willingness to collaborate, or not. It may be a shared commitment to the future, a shared need for livelihoods, or the absence of a shared commitment to respect for all actors (e.g., sexism or colonialism). This deeper analysis allows for stronger theory building and is the reason why we introduce a critical realist framing because its layered ontology encourages the search for deeper causal mechanisms. Critical realist scholars like Danermark (2005) and Price (2014) provide useful analytic tools for this purpose.

\section{CONCLUSION}

There is a growing array of large, complex, multifaceted collaborative initiatives in place-based social-ecological systems. These initiatives are characterized by many multiples: multiple resources, actors, objectives, scales, and institutions. The initiatives experience significant challenges in fostering effective and equitable collaboration for achieving social-ecological sustainability outcomes for natural resource management and conservation. Contextual factors set this emerging group of multifaceted collaborative initiatives apart from others, posing a particular challenge. Along with these challenges experienced in practice, the gaps in existing theory on collaboration have led us to propose a clearer focus on the contextual factors that influence multifaceted collaborative processes and outcomes.

Drawing on realist evaluation approaches, together with a critical realist metatheory, we have therefore proposed a critical realist methodology to support analysis and comparison of factors that influence collaboration. This methodology applies contextmechanism-outcomes schema to describe, analyze, and compare cases of multifaceted collaboration to better understand the influence of context on collaboration. Applying this focus on context through the $\mathrm{CMO}$ methodology enables a more nuanced, situated understanding of collaboration, while also contributing to a more generalized understanding of how contextual factors influence collaborative processes and social-ecological sustainability outcomes. With its openness to inter- and transdisciplinary methodologies and diverse world views, this critical realist methodology can also be used in an iterative and cyclical way to support in-context transdisciplinary learning together with practitioners.

We invite other researchers and practitioners who are curious about "what works, for whom, in what circumstances and why? " in complex collaborative initiatives in SES to sharpen their focus on contextual factors that influence collaboration, by experimenting with the context-mechanisms-outcomes methodology. We welcome comments, debate, and collaborative research on the challenges facing practitioners and researchers in understanding and facilitating multifaceted collaborative processes for socialecological sustainability.

Responses to this article can be read online at: http://www.ecologyandsociety.org/issues/responses. $\mathrm{php} / 11527$

\section{Acknowledgments:}

This research is a product of the Collaborative Management and Governance Working Group of the Programme on Ecosystem Change and Society (PECS). The authors acknowledge funding provided for Jessica Cockburn through the Rhodes University Postdoctoral Fellowship, and support to Georgina Cundill by the National Research Foundation of South Africa (NRF) through grants 93446 and 90694 . The financial assistance of the NRF toward this research is hereby acknowledged. We also appreciate the helpful input of participants of Michael Schoon's lab group at the School of Sustainability, Arizona State University (in particular Ute Brady and Candice Carr Kelman). We thank the two anonymous reviewers who engaged thoughtfully with our manuscript and provided important guidance for improving it.

\section{Data Availability Statement:}

Not applicable. This is a methodology paper and has no data. 


\section{LITERATURE CITED}

Aburto, J. A., and C. F. Gaymer. 2018. Struggling with socialecological mismatches in marine management and conservation at Easter Island. Marine Policy 92:21-29. https://doi.org/10.1016/ j.marpol.2018.01.012

Aburto, J. A., C. F. Gaymer, and G. Cundill. 2017. Towards local governance of marine resources and ecosystems on Easter Island. Aquatic Conservation: Marine and Freshwater Ecosystems 27 (2):353-371. https://doi.org/10.1002/aqc.2665

Aburto, J. A., W. B. Stotz, and G. Cundill. 2014. Social-ecological collapse: turf governance in the context of highly variable resources in Chile. Ecology and Society 19(1):2 https://doi. org/10.5751/ES-06145-190102

Alexander, S. M., and D. Armitage. 2015. A social relational network perspective for mpa science. Conservation Letters 8 (1):1-13. http://doi.org/10.1111/conl.12090

Ansell, C., and A. Gash. 2007. Collaborative governance in theory and practice. Journal of Public Administration Research and Theory 18:543-571. http://dx.doi.org/10.1093/jopart/mum032

Armitage, D., F. Berkes, and N. Doubleday. 2007. Adaptive comanagement: collaboration, learning, and multi-level governance. UBC Press, Vancouver, British Columbia, Canada.

Audouin, M., R. Preiser, S. Nienaber, L. Downsborough, J. Lanz, and S. Mavengahama. 2013. Exploring the implications of critical complexity for the study of social-ecological systems. Ecology and Society 18(3):12. http://doi.org/10.5751/ES-05434-180312

Ayala-Orozco, B., J. A. Rosell, J. Merçon, I. Bueno, G. AlatorreFrenk, A. Langle-Flores, and A. Lobato. 2018. Challenges and strategies in place-based multi-stakeholder collaboration for sustainability: learning from experiences in the global south. Sustainability 10(9):3217. http://doi.org/10.3390/su10093217

Baggio, J. A., A. J. Barnett, I. Perez-Ibarra, U. Brady, E. Ratajczyk, N. Rollins, C. Rubiños, H. C. Shin, D. J. Yu, R. Aggarwal, J. M. Anderies, and M. A. Janssen. 2016. Explaining success and failure in the commons: the configural nature of Ostrom's institutional design principles. International Journal of the Commons 10(2):417-436. https://doi.org/10.18352/ijc.634

Balvanera, P., R. Calderón-Contreras, A. J. Castro, M. R. FelipeLucia, I. R. Geijzendorffer, S. Jacobs, B. Martín-López, U. Arbieu, C. I. Speranza, B. Locatelli, N. P. Harguindeguy, I. R. Mercado, M. J. Spierenburg, A. Vallet, L. Lynes, and L. Gillson. 2017. Interconnected place-based social-ecological research can inform global sustainability. Current Opinion in Environmental Sustainability 29:1-7. http://doi.org/10.1016/j.cosust.2017.09.005

Bark, R. H., C. J. Robinson, and K. W. Flessa. 2016. Tracking cultural ecosystem services: water chasing the Colorado River restoration pulse flow. Ecological Economics 127:165-172. https:// doi.org/10.1016/j.ecolecon.2016.03.009

Barnaud, C., E. Corbera, R. Muradian, N. Salliou, C. Sirami, A. Vialatte, J.-P. Choisis, N. Dendoncker, R. Mathevet, C. Moreau, V. Reyes-García, M. Boada, M. Deconchat, C. Cibien, S. Garnier, R. Maneja, and M. Antona. 2018. Ecosystem services, social interdependencies, and collective action: a conceptual framework. Ecology and Society 23(1):15. https://doi. org/10.5751/ES-09848-230115
Barnaud, C., and A. van Paassen. 2013. Equity, power games, and legitimacy dilemmas of participatory natural resource management. Ecology and Society 18(2):21. http://dx.doi. org/10.5751/ES-05459-180221

Barnaud, C., A. van Paassen, G. Trébuil, T. Promburom, and F. Bousquet. 2010. Dealing with power games in a companion modelling process: lessons from community water management in Thailand highlands. Journal of Agricultural Education and Extension 16(1):55-74. https://doi.org/10.1080/13892240903533152

Barnett, A. J., J. A. Baggio, H. C. Shin, D. J. Yu, I. Perez-Ibarra, C. Rubiños, U. Brady, E. Ratajczyk, N. Rollins, R. Aggarwal, J. M. Anderies, and M. A. Janssen. 2016. An iterative approach to case study analysis: insights from qualitative analysis of quantitative inconsistencies. International Journal of the Commons 10(2):467-494. https://doi.org/10.18352/ijc.632

Berkes, F. 2006. From community-based resource management to complex systems: the scale issue and marine commons. Ecology and Society 11(1):45. https://doi.org/10.5751/ES-01431-110145

Bhaskar, R. 2010. Contexts of interdisciplinarity: interdisciplinarity and climate change, Pages 1-24 in R. Bhaskar, C. Frank, K. G. Høyer, P. Næss, and J. Parker, editors. Interdisciplinarity and climate change: transforming knowledge and practice for our global future. Routledge, Oxon, UK. https://doi.org/10.4324/9780203855317

Bhaskar, R. 2016. Enlightened common sense: the philosophy of critical realism. Routledge, Oxon, UK. https://doi. org/10.4324/9781315542942

Bhaskar, R., C. Frank, K. G. Høyer, P. Næss, and J. Parker. 2010. Interdisciplinarity and climate Change: transforming knowledge and practice for our global future. Routledge, Oxon, UK. https:// doi.org/10.4324/9780203855317

Bodin, Ö. 2017. Collaborative environmental governance: achieving collective action in social-ecological systems. Science 357(6352):eaan1114. http://doi.org/10.1126/science.aan1114

Brisbois, M. C., and R. C. de Loö. 2016. State roles and motivations in collaborative approaches to water governance: a power theory-based analysis. Geoforum 74:202-212. https://doi. org/10.1016/j.geoforum.2016.06.012

Cárcamo, P. F., R. Garay-Flühmann, and C. F. Gaymer. 2014. Collaboration and knowledge networks in coastal resources management: how critical stakeholders interact for multiple-use marine protected area implementation. Ocean and Coastal Management 91:5-16. https://doi.org/10.1016/j.ocecoaman.2014.01.007

Carlsson, L., and F. Berkes. 2005. Co-management: concepts and methodological implications. Journal of Environmental Management 75(1):65-76. https://doi.org/10.1016/j.jenvman.2004.11.008

Carpenter, S. R., C. Folke, A. Norström, O. Olsson, L. Schultz, B. Agarwal, P. Balvanera, B. Campbell, J. C. Castilla, W. Cramer, R. DeFries, P. Eyzaguirre, T. P. Hughes, S. Polasky, Z. Sanusi, R. Scholes, and M. Spierenburg. 2012. Program on ecosystem change and society: an international research strategy for integrated social-ecological systems. Current Opinion in Environmental Sustainability 4(1):134-138. http://dx.doi.org/10.1016/j.cosust.2012.01.001

Carr Kelman, C., U. Brady, J. Baggio, J. Lee, C. Rojas, J. Srinivasan, S. Vallury, and M. Schoon. 2018. Practitioner brief on factors for effective environmental management collaboration. 
CBIE Working Paper Series \#Cbie-2018-003. Center for Behavior, Institutions and the Environment, Arizona State University, Tempe, Arizona, USA. [online] URL: https:// complexity.asu.edu/sites/default/files/papers/cbie_wp_2018-003_0. pdf

Cleaver, F. 2002. Reinventing institutions: bricolage and the social embeddedness of natural resource management. European Journal of Development Research 14(2):11-30. https://doi. org/10.1080/714000425

Cleaver, F., and L. Whaley. 2018. Understanding process, power, and meaning in adaptive governance: a critical institutional reading. Ecology and Society 23(2):49. https://doi.org/10.5751/ ES-10212-230249

Clement, S., A. Guerrero Gonzalez, and C. Wyborn. 2020. Understanding effectiveness in its broader context: assessing case study methodologies for evaluating collaborative conservation governance. Society and Natural Resources 33(4):462-483. https:// doi.org/10.1080/08941920.2018.1556761

Cockburn, J. J. 2018. Stewardship and collaboration in multifunctional landscapes: a transdisciplinary enquiry. Dissertation. Department of Environmental Science, Rhodes University, Grahamstown, South Africa. [online] URL: http://vital.seals.ac. za:8080/vital/access/manager/PdfViewer/vital:27998/SOURCE1? viewPdfInternal $=1$

Cockburn, J., G. Cundill, S. Shackleton, A. Cele, S. F. Cornelius, V. Koopman, J.-P. le Roux, N. McLeod, M. Rouget, S. Schroder, D. Van den Broeck, D. R. Wright, and M. Zwinkels. 2020. Relational hubs for collaborative landscape stewardship. Society and Natural Resources 33:681-693. https://doi.org/10.1080/0894$\underline{1920.2019 .1658141}$

Cockburn, J., G. Cundill, C. Shackleton, and M. Rouget. 2018. Towards place-based research to support social-ecological stewardship. Sustainability 10(5):14-34. http://doi.org/10.3390/ $\underline{\mathrm{su} 10051434}$

Cockburn, J., G. Cundill, S. Shackleton, M. Rouget, M. Zwinkels, S. Cornelius, L. Metcalfe, and D. van den Broeck. 2019. Collaborative stewardship in multifunctional landscapes: toward relational, pluralistic approaches. Ecology and Society 24(4):32. https://doi.org/10.5751/es-11085-240432

Coetzer, K. L., E. T. F. Witkowski, and B. F. N. Erasmus. 2014. Reviewing biosphere reserves globally: effective conservation action or bureaucratic label? Biological Reviews 89(1):82-104. http://doi.org/10.1111/brv.12044

Cornell, S. 2010. Climate change: brokering interdisciplinarity across the phyisical and social sciences. Pages 116-134 in R. Bhaskar, C. Frank, K. G. Høyer, P. Næss, and J. Parker, editors. Interdisciplinarity and climate change: transforming knowledge and practice for our global future. Routledge, Oxon, UK. https://doi. org//10.4324/9780203855317

Cote, M., and A. J. Nightingale. 2011. Resilience thinking meets social theory: situating change in socio-ecological systems (SES) research. Progress in Human Geography 36(4):475-489. http://dx. doi.org/10.1177/0309132511425708
Creswell, J. W. 2009. Research design: qualitative, quantitative and mixed methods approaches. Sage, Thousand Oaks, California, USA.

Cundill, G., G. Thondhlana, L. Sisitka, S. Shackleton, and M. Blore. 2013. Land claims and the pursuit of co-management on four protected areas in South Africa. Land Use Policy 35:171-178. http://dx.doi.org/10.1016/j.landusepol.2013.05.016

Danermark, B., M. Ekström, L. Jakobson, and J. C. Karlson. 2005. Explaining society: critical realism in the social sciences. Routledge, London, UK.

Díaz, S., S. Demissew, J. Carabias, C. Joly, M. Lonsdale, N. Ash, A. Larigauderie, J. R. Adhikari, S. Arico, A. Báldi, A. Bartuska, I. A. Baste, A. Bilgin, E. Brondizio, K. M. A. Chan, V. E. Figueroa, A. Duraiappah, M. Fischer, R. Hill, T. Koetz, P. Leadley, P. Lyver, G. M. Mace, B. Martin-Lopez, M. Okumura, D. Pacheco, U. Pascual, E. S. Pérez, B. Reyers, E. Roth, O. Saito, R. J. Scholes, N. Sharma, H. Tallis, R. Thaman, R. Watson, T. Yahara, Z. A. Hamid, C. Akosim, Y. Al-Hafedh, R. Allahverdiyev, E. Amankwah, S. T. Asah, Z. Asfaw, G. Bartus, L. A. Brooks, J. Caillaux, G. Dalle, D. Darnaedi, A. Driver, G. Erpul, P. EscobarEyzaguirre, P. Failler, A. M. M. Fouda, B. Fu, H. Gundimeda, S. Hashimoto, F. Homer, S. Lavorel, G. Lichtenstein, W. A. Mala, W. Mandivenyi, P. Matczak, C. Mbizvo, M. Mehrdadi, J. P. Metzger, J. B. Mikissa, H. Moller, H. A. Mooney, P. Mumby, H. Nagendra, C. Nesshover, A. A. Oteng-Yeboah, G. Pataki, M. Roué, J. Rubis, M. Schultz, P. Smith, R. Sumaila, K. Takeuchi, S. Thomas, M. Verma, Y. Yeo-Chang, and D. Zlatanova. 2015. The IPBES conceptual framework - connecting nature and people. Current Opinion in Environmental Sustainability 14:1-16. http:// dx.doi.org/10.1016/j.cosust.2014.11.002

Díaz, S., U. Pascual, M. Stenseke, B. Martín-López, R. T. Watson, Z. Molnár, R. Hill, K. M. A. Chan, I. A. Baste, K. A. Brauman, S. Polasky, A. Church, M. Lonsdale, A. Larigauderie, P. W. Leadley, A. P. E. van Oudenhoven, F. van der Plaat, M. Schröter, S. Lavorel, Y. Aumeeruddy-Thomas, E. Bukvareva, K. Davies, S. Demissew, G. Erpul, P. Failler, C. A. Guerra, C. L. Hewitt, H. Keune, S. Lindley, and Y. Shirayama. 2018. Assessing Nature's contributions to people. Science 359(6373):270-272. https://doi. org/10.1126/science.aap8826

Djenontin, I. N. S., and A. M. Meadow. 2018. The art of coproduction of knowledge in environmental sciences and management: lessons from international practice. Environmental Management 61(6):885-903. https://doi.org/10.1007/s00267-018-1028-3

Douthwaite, B., and E. Hoffecker. 2017. Towards a complexityaware theory of change for participatory research programs working within agricultural innovation systems. Agricultural Systems 155:88-102. https://doi.org/10.1016/j.agsy.2017.04.002

Douthwaite, B., J. Mayne, C. McDougall, and R. PazYbarnegaray. 2017. Evaluating complex interventions: a theorydriven realist-informed approach. Evaluation 23(3):294-311. https://doi.org/10.1177/1356389017714382

Duncan, T., J. Villarreal-Rosas, J. Carwardine, S. T. Garnett, and C. J. Robinson. 2018. Influence of environmental governance regimes on the capacity of indigenous peoples to participate in conservation management. PARKS - International Journal of Protected Areas and Conservation 24.2:87-102. 
Emerson, K., T. Nabatchi, and S. Balogh. 2012. An integrative framework for collaborative governance. Journal of Public Administration Research and Theory 22(1):1-29. https://doi. org/10.1093/jopart/mur011

Fabricius, C., E. Koch, S. Turner, and H. Magome. 2013. Rights resources and rural development: community-based natural resource management in Southern Africa. Routledge, London, UK. https://doi.org/10.4324/9781849772433

Ferreyra, C., R. C. de Loë, and R. D. Kreutzwiser. 2008. Imagined communities, contested watersheds: challenges to integrated water resources management in agricultural areas. Journal of Rural Studies 24(3):304-321. https://doi.org/10.1016/j. jrurstud.2007.11.001

Folke, C., T. Hahn, P. Olsson, and J. Norberg. 2005. Adaptive governance of social-ecological systems. Annual Review of Environment and Resources 30(1):441-473. https://doi.org/10.1146/ annurev.energy.30.050504.144511

Gorski, P. S. 2013. What is critical realism? And why should you care? Contemporary Sociology: a Journal of Reviews 42 (5):658-670. https://doi.org/10.1177/0094306113499533

Harrington, C. 2017. The political ontology of collaborative water governance. Water International 42(3):254-270. https://doi. org/10.1080/02508060.2017.1309507

Hill, R., J. Davies, I. C. Bohnet, C. J. Robinson, K. Maclean, and P. L. Pert. 2015. Collaboration mobilises institutions with scaledependent comparative advantage in landscape-scale biodiversity conservation. Environmental Science and Policy 51:267-277. https://doi.org/10.1016/j.envsci.2015.04.014

Hill, R., C. Grant, M. George, C. J. Robinson, S. Jackson, and N. Abel. 2012. A typology of indigenous engagement in Australian environmental management: implications for knowledge integration and social-ecological system sustainability. Ecology and Society 17(1):23. https://doi.org/10.5751/ES-04587-170123

Hinkel, J., M. E. Cox, M. Schlüter, C. R. Binder, and T. Falk. 2015. A diagnostic procedure for applying the social-ecological systems framework in diverse cases. Ecology and Society 20(1):32. http://dx.doi.org/10.5751/ES-07023-200132

Ifejika Speranza, C., B. Kiteme, U. Wiesmann, and J. Jörin. 2018. Community-based water development projects, their effectiveness, and options for improvement: lessons from Laikipia, Kenya. African Geographical Review 37(3):192-208. https://doi. org/10.1080/19376812.2016.1253485

Imperial, M. T. 2005. Using collaboration as a governance strategy: lessons from six watershed management programs. Administration and Society 37(3):281-320. https://doi. org/10.1177/0095399705276111

Lansing, D., R.-C. Collard, J. Dempsey, J. Sundberg, N. Heynen, B. Büscher, W. Dressler, and R. Fletcher. 2015. Nature ${ }^{\mathrm{TM}}$ Inc.: environmental conservation in a neoliberal age. Environment and Planning A 47(11):2389-2408. https://doi.org/10.1177/0308518x15605405

Laplaza, A., I. G. L. P. Tanaya, and Suwardji. 2017. Adaptive comanagement in developing world contexts: a systematic review of adaptive comanagement in Nusa Tenggara Barat, Indonesia. Climate Risk Management 17:64-77. https://doi.org/10.1016/j. crm.2017.04.003
Leach, M., K. Raworth, and J. Rockström. 2013. Between social and planetary boundaries: navigating pathways in the safe and just space for humanity. Pages 84-89 in ISSC and UNESCO, editors. World social science report 2013, changing global environments. OECD and UNESCO, Paris, France.

Levin, S., T. Xepapadeas, A.-S. Crépin, J. Norberg, A. de Zeeuw, C. Folke, T. Hughes, K. Arrow, S. Barrett, G. Daily, P. Ehrlich, N. Kautsky, K.-G. Mäler, S. Polasky, M. Troell, J. R. Vincent, and B. Walker. 2013. Social-ecological systems as complex adaptive systems: modeling and policy implications. Environment and Development Economics 18(2):111-132. https://doi.org/10.1017/ $\underline{\mathrm{S} 1355770 \mathrm{X} 12000460}$

Lobe, K., and F. Berkes. 2004. The padu system of communitybased fisheries management: change and local institutional innovation in South India. Marine Policy 28(3):271-281.

Lubell, M. 2015. Collaborative partnerships in complex institutional systems. Current Opinion in Environmental Sustainability 12:41-47. http://dx.doi.org/10.1016/j.cosust.2014.08.011

Margerum, R. D., and C. J. Robinson. 2016. The challenges of collaboration in environmental governance: barriers and responses. Edward Elgar, Cheltenham, UK.

Mathevet, R., M. Antona, C. Barnaud, C. Fourage, G. Trébuil, and S. Aubert. 2014. Contexts and dependencies in the ComMod processes. Pages 103-125 in M. Étienne, editor. Companion modelling. Springer, Dordrecht, The Netherlands. https://doi. org/10.1007/978-94-017-8557-0 5

Mayne, J. W., and E. Stern. 2013. Impact evaluation of natural resource management research programs: a broader view. Aciar Impact Assessment Series Report No. 84. Australian Centre for International Agricultural Research, Canberra, Australia.

McLain, R., S. Lawry, and M. Ojanen. 2018. Fisheries' property regimes and environmental outcomes: a realist synthesis review. World Development 102:213-227. https://doi.org/10.1016/j. worlddev.2017.09.016

Mingers, J. 2004. Paradigm wars: ceasefire announced who will set up the new administration? Journal of Information Technology 19(3):165-171. https://doi.org/10.1057/palgrave.jit.2000021

Mingers, J. 2011. Explanatory mechanisms: the contribution of critical realism and systems thinking/cybernetics. Working Paper No. 241. University of Kent, Canterbury, Canterbury, UK.

Millenium Ecosystem Assessment (MEA). 2005. Millennium Ecosystem Assessment: ecosystems and human well-being-current state and trends. Island, Washington, D.C., USA. [online] URL: https://www.millenniumassessment.org/documents/document.766. aspx.pdf

Morgan, D. L. 2007. Paradigms lost and pragmatism regained: methodological implications of combining qualitative and quantitative methods. Journal of Mixed Methods Research 1 (1):48-76. https://doi.org/10.1177/2345678906292462

Nastar, M., C. S. Boda, and L. Olsson. 2018. A critical realist inquiry in conducting interdisciplinary research. Ecology and Society 23(3):41. https://doi.org/10.5751/ES-10218-230341

North, D. C. 1991. Institutions. Journal of Economic Perspectives 5(1):97-112. https://pubs.aeaweb.org/doi/pdfplus/10.1257/jep.5.1.97 
Oberlack, C., S. Boillat, S. Brönnimann, J.-D. Gerber, A. Heinimann, C. I. Speranza, P. Messerli, S. Rist, and U. Wiesmann. 2018. Polycentric governance in telecoupled resource systems. Ecology and Society 23(1):16. https://doi.org/10.5751/ES-09902-230116

O’Farrell, P. J., B. Reyers, D. C. Le Maitre, S. J. Milton, B. Egoh, A. Maherry, C. Colvin, D. Atkinson, W. De Lange, J. N. Blignaut, and R. M. Cowling. 2010. Multi-functional landscapes in semi arid environments: implications for biodiversity and ecosystem services. Landscape Ecology 25(8):1231-1246. http://dx.doi. org/10.1007/s10980-010-9495-9

Ostrom, E. 1990. Governing the commons. The evolution of institutions for collective action. Cambridge University Press, New York, New York, USA.

Ostrom, E. 2005. Understanding institutional diversity. Princeton University Press, Princeton, New Jersey, USA.

Ostrom, E. 2009. A general framework for analyzing sustainability of social-ecological systems. Science 325 (5939):419-422. https://doi.org/10.1126/science.1172133

Ostrom, E., M. A. Janssen, and J. M. Anderies. 2007. Going beyond panaceas. Proceedings of the National Academy of Sciences 104(39):15176-15178. https://doi.org/10.1073/pnas.0701886104

Paredes, F., D. Flores, A. Figueroa, C. F. Gaymer, and J. A. Aburto. 2019. Science, capacity building and conservation knowledge: the empowerment of the local community for marine conservation in Rapa Nui. Aquatic Conservation: Marine and Freshwater Ecosystems 29(S2):130-137. https://doi.org/10.1002/ aqc. 3114

Patterson, J. 2017. Purposeful collective action in ambiguous and contested situations: exploring 'enabling capacities' and crosslevel interplay. International Journal of the Commons 11 (1):248-274. http://doi.org/10.18352/ijc.696

Pawson, R. 2013. The science of evaluation: a realist manifesto. Sage, Thousand Oaks, California, USA. https://doi. org/10.4135/9781473913820

Pawson, R. 2016. The ersatz realism of critical realism: a reply to Porter. Evaluation 22(1):49-57. https://doi.org/10.1177/1356389015605206

Pawson, R., and N. Tilley. 2004. Realist evaluation. In Realistic evaluation. Sage, Thousand Oaks, California, USA. [online] URL: http://www.communitymatters.com.au/RE_chapter.pdf

Plummer, R., and D. Armitage. 2007. A resilience-based framework for evaluating adaptive co-management: linking ecology, economics and society in a complex world. Ecological Economics 61(1):62-74. https://doi.org/10.1016/j.ecolecon.2006.09.025

Plummer, R., J. Baird, A. Dzyundzyak, D. Armitage, Ö. Bodin, and L. Schultz. 2017. Is adaptive co-management delivering? Examining relationships between collaboration, learning and outcomes in Unesco biosphere reserves. Ecological Economics 140:79-88. https://doi.org/10.1016/j.ecolecon.2017.04.028

Poteete, A. R. 2012. Levels, scales, linkages, and other 'multiples' affecting natural resources. International Journal of the Commons 6(2):134-150. http://dx.doi.org/10.18352/ijc.318

Preiser, R. 2019. Identifying general trends and patterns in complex systems research: an overview of theoretical and practical implications. Systems Research and Behavioral Science 36(5):706-714. https://doi.org/10.1002/sres.2619

Price, L. 2014. Critical realist versus mainstream interdisciplinarity. Journal of Critical Realism 13(1):52-76. https://doi. org/10.1179/1476743013Z.00000000019

Pulver, S., N. Ulibarri, K. L. Sobocinski, S. M. Alexander, M. L. Johnson, P. F. McCord, and J. Dell'Angelo. 2018. Frontiers in socio-environmental research: components, connections, scale, and context. Ecology and Society 23(3):23. https://doi. org/10.5751/ES-10280-230323

Robards, M. D., M. L. Schoon, C. L. Meek, and N. L. Engle. 2011. The importance of social drivers in the resilient provision of ecosystem services. Global Environmental Change 21 (2):522-529. https://doi.org/10.1016/j.gloenvcha.2010.12.004

Robinson, C. J., R. H. Bark, D. Garrick, and C. A. Pollino. 2015. Sustaining local values through river basin governance: community-based initiatives in Australia's Murray-Darling basin. Journal of Environmental Planning and Management 58 (12):2212-2227. https://doi.org/10.1080/09640568.2014.976699

Robinson, C. J., G. James, and P. J. Whitehead. 2016. Negotiating indigenous benefits from payment for ecosystem service (PES) schemes. Global Environmental Change 38:21-29. https://doi. org/10.1016/i.gloenvcha.2016.02.004

Rogers, P. J. 2008. Using programme theory to evaluate complicated and complex aspects of interventions. Evaluation 14 (1):29-48. https://doi.org/10.1177/1356389007084674

Sandström, C. 2009. Institutional dimensions of comanagement: participation, power, and process. Society and Natural Resources 22(3):230-244. https://doi.org/10.1080/08941920802183354

Saunders, F. P. 2014. The promise of common pool resource theory and the reality of commons projects. International Journal of the Commons 8(2):636-656. https://doi.org/10.18352/ijc.477

Sayer, A. 2010. Method in Social Science. Routledge, Oxon, UK.

Schoon, M., A. York, A. Sullivan, and J. Baggio. 2017. The emergence of an environmental governance network: the case of the Arizona borderlands. Regional Environmental Change 17 (3):677-689. https://doi.org/10.1007/s10113-016-1060-X

Schultz, L., A. Duit, and C. Folke. 2011. Participation, adaptive co-management, and management performance in the world network of biosphere reserves. World Development 39(4):662-671. http://dx.doi.org/10.1016/j.worlddev.2010.09.014

Tengö, M., E. S. Brondizio, T. Elmqvist, P. Malmer, and M. Spierenburg. 2014. Connecting diverse knowledge systems for enhanced ecosystem governance: the multiple evidence base approach. AMBIO 43(5):579-591. http://dx.doi.org/10.1007/ s13280-014-0501-3

Thondhlana, G., S. Shackleton, and J. Blignaut. 2015. Local institutions, actors, and natural resource governance in Kgalagadi Transfrontier Park and surrounds, South Africa. Land Use Policy 47:121-129. https://doi.org/10.1016/j.landusepol.2015.03.013

von der Porten, S., R. de Loë, and R. Plummer. 2015. Research article: collaborative environmental governance and indigenous peoples: recommendations for practice. Environmental Practice 17(2):134-144. https://doi.org/10.1017/S146604661500006X 
Ward, M. 2017. An evaluation of the community reforestation research programme. Creating Sustainable Value, Durban, South Africa.

Watts, M. 2004. Resource curse? Governmentality, oil and power in the Niger Delta, Nigeria. Geopolitics 9(1):50-80. https://doi. org/10.1080/14650040412331307832

Westhorp, G. 2014. Realist impact evaluation: an introduction. Methods Lab, Overseas Development Institute, London, UK.

Wiesmann, U., S. Biber-Klemm, W. Grossenbacher-Mansuy, G. H. Hadorn, H. Hoffmann-Riem, D. Joye, C. Pohl, and E. Zemp. 2008. Enhancing transdisciplinary research: a synthesis in fifteen propositions. Pages 433-441 in G. Hirsch Hadorn, H. HoffmannRiem, S. Biber-Klemm, W. Grossenbacher-Mansuy, D. Joye, C. Pohl, U. Wiesmann, and E. Zemp, editors. Handbook of transdisciplinary research. Springer, New York, New York, USA. https://doi.org/10.1007/978-1-4020-6699-3 29

Wilson, E., and F. Stammler. 2016. Beyond extractivism and alternative cosmologies: Arctic communities and extractive industries in uncertain times. Extractive Industries and Society 3 (1):1-8. https://doi.org/10.1016/j.exis.2015.12.001

Wolin, S.S. 2008. Democracy incorporated: managed democracy and the specter of inverted totalitarianism. Princeton University Press, Princeton, New Jersey, USA.

Wollenberg, E., J. Anderson, and C. López. 2005. Though all things differ: pluralism as a basis for cooperation in forests. CIFOR, Bogor, Indonesia. [online] URL: http://www.cifor.org/publications/ pdf_files/Books/BWollenberg0501.pdf

Wondolleck, J. M., and S. L. Yaffee. 2000. Making collaboration work: lessons from innovation in natural resource management. Island, Washington, D.C., USA.

Zachrisson, A., and K. Beland Lindahl. 2013. Conflict resolution through collaboration: preconditions and limitations in forest and nature conservation controversies. Forest Policy and Economics 33:39-46. https://doi.org/10.1016/j.forpol.2013.04.008 